\title{
RESPON PETANI PADA PENERAPAN TEKNOLOGI USAHATANI VUB PADI INPARI 24 DI KABUPATEN PANGKEP
}

\author{
The Response of Farmers to The NSV Farming Application of Inpari 24 \\ Rice Technology in Pangkep Regency
}

\author{
Warda Halil*, Eka Triana Yuliarsih, Yusmasari dan Idaryani \\ Balai Pengkajian Teknologi Pertanian Sulawesi Selatan \\ Jl. Perintis Kemerdekaan Km.17,5, Sudiang \\ *e-mail: warda69.halil@gmail.com
}

Received: 29 Oktober 2021; Accepted: 23 November 2021; Published: 25 Desember 2021

\begin{abstract}
ABSTRAK
Varietas Unggul Baru (VUB) merupakan salah satu teknologi yang berperan penting dalam peningkatan kuantitas dan kualitas produk pertanian. Salah satu VUB yang mempunyai daya saing dan nilai ekonomi, baik rasa maupun manfaatnya adalah Inpari 24/beras merah. Tidak banyak petani yang bersedia memproduksi beras merah, meskipun harganya tinggi, hal ini berkaitan dengan sifat inovasi dari teknologi padi yang diterapkan. Tujuan kegiatan ini untuk mengetahui respon petani pada penerapan teknologi padi Inpari 24. Metode penelitian dilakukan dengan melakukan wawancara langsung dengan petani menggunakan kuesioner dengan jumlah responden sebanyak 25 orang. Analisis data menggunakan Teknik skor.Data dianalisis secara deskriptif. Kesimpulan dari kegiatan ini bahwa menurut petani, teknologi yang Sulit dilaksanakan pada penerapan teknologi Inpari 24 adalah Penggunaan VUB, pemberian bahan organik, sistem tanam legowo, pemupukan berdasarkan kebutuhan tanaman dan status hara tanah, pengendalian OPT dengan pendekatan PHT, penyiangan dengan landak/gasrok dan Pasca Panen. Teknologi yang mudah dilakukan adalah : penggunaan bibit muda ( $<21$ hari), dan tanam bibit 1-3 batang per rumpun, penggunaan benih bermutu dan berlabel, pengolahan tanah sesuai musim dan pola tanam, dan panen tepat waktu dan gabah segera dirontok.
\end{abstract}

Kata kunci: Respon, teknologi padi, varietas unggul baru, inpari 24

\section{ABSTRACT}

New Superior Varieties (NSV) is a technology that plays an important role in increasing the quantity and quality of agricultural products. One of the NSVs that has competitiveness and economic value, both in terms of taste and benefits, is Inpari 24/brown rice. Not many farmers are willing to produce brown rice, even though the price is high, this is related to the innovative nature of the applied rice technology. The purpose of this activity is to determine the response of farmers to the application of Inpari 24 rice technology. The methodology is carried out by conducting direct interviews with farmers using a questionnaire with a total of 25 respondents. Data analysis used score technique. Data were analyzed descriptively. The conclusion of this activity is that according to farmers, the technology that is difficult to implement in the application of Inpari 24 technology is the use of NSV, organic matter application, legowo planting system, fertilization based on plant needs and soil nutrient status, pest control with IPM approach, weeding with hedgehogs/gasrok and Post-harvest. The technologies that are easy to implement are: the use of young seedlings (<21 days), and planting 1-3 stems per clump, the use of quality and labeled seeds, tillage according to the season and cropping pattern, and timely harvesting and threshing of the grain.

Keywords: Response, rice technology, new superior varieties, inpari 24

Diterbitkan Oleh, 


\section{PENDAHULUAN}

Luas tanaman padi sawah disulawesi selatan 995,335 ha dengan produksi rata-rata 5,292 t/ha (data BPS 2015). Produksi ini masih tergolong rendah dibandingkan dengan produksi beberapa hasil penetian yang telah dilakukan. Salah satu yang mengakibatkan rendahnya produksi padi di Sulawesi Selatan adalah penggunaan teknologi Varieta Unggul Baru (VUB) di tingkat petani masih rendah. Penggunaan vaietas unggul baru padi, merupakan salah satu komponen yang berpengaruh terhadap penggunaan benih bermutu, yang akan berakibat terhadap produksi yang dihasilkan.

Varietas unggul baru merupakan salah satu teknologi yang berperan penting dalam peningkatan kuantitas dan kualitas produk pertanian (Badan Litbang Pertanian, 2007), hal tersebut terbukti pada tahun 1984 indonesia mencapai swasembada beras. Varietas unggul padi merupakan inovasi teknologi yang berpeluang tinggi diadopsi oleh petani, karena mudah dilakukan, daya hasil tinggi dan tahan terhadap hama dan penyakit tertentu (Arsyad 2011).

Saat ini pemerintah sudah melepas berbagai macam varietas unggul baru padi dan sebagian sudah diadopsi oleh petani. Pemilihan varietas oleh petani di sesuaikan dengan kondisi lingkungan setempat, berdaya hasil dan bernilai ekonomi tinggi. Penggunaan varietas padi merupakan teknologi yang mudah diadopsi oleh petani, karena murah dan penggunaannya sangat praktiss. (Taufik, et al. 2011).

Salah satu varietas unggul padi yang yang saat ini dikembangkan oleh Badan Litbang pertanian adalah VUB Inpari 24( beras merah). Beras merah merupakan beras yang tidak melalui penggilingan sempurna, sehingga kulit ari masih menempel. Indonesia memiliki beragam varietas beras merah lokal dengan kandungan gizi masingmasing berbeda sesuai dengan tempat tumbuhnya. Di Sulawesi Selatan dikenal jenis beras merah seperti beras Malino, Pulu Mandoti dan Pare Birrang. Beberapa dari jenis beras merah local mempunyai sifat pera/pulen, dan aromatic.

Saat ini, permintaan beras merah semakin hari semakin meningkat dan disisi lain ketersediaan pasar sangat terbatas. Produksi beras merah masih rendah yaitu sekitar 2-3 ton/ha. Tingginya permintaan konsumen tidak diimbangi dengan pengembangan produksi dan minat masyarakat dalam pemanfaatan beras merah. Masyarakat Indonesia menganggap beras merah hanya dikonsumsi oleh orang yang mempunyai penyakit diabetes dan kolestrol tinggi. Pada kenyataannya, beras merah memberikan asupan gizi lebih baik bagi tubuh, karena pada kulit ari beras merah kaya akan serat dan minyak alami. Kandungan utama pada beras merah adalah karbohidrat. Berdasarkan Tabel Komposisi Pangan Indonesia (2009), kandungan karbohidrat dalam 100 gram beras merah adalah 76,2 gram. Tingginya kadar karbohidrat tersebut menyebabkan beras merah ideal dijadikan sebagai bahan pangan pokok bagi penduduk di berbagai negara. Beberapa penelitian juga menunjukkan bahwa, beras merah dapat menjadi sumber antioksidan yang baik. Antioksidan yang dihasilkan ini dapat menghambat berbagai penyakit, seperti kardiovaskuler, kanker, diabetes, ataupun hipertensi. Beras merah menghasilkan antioksidan yang berasal dari pigmen antosianin (Astawan, 2009). Varietas Unggul Baru (VUB) inpari 24, memiliki tekstur nasi pulen dan memiliki kadar amilosa 18 persen serta memiliki potensi hasil 7,7 ton/ha gabah kering giling (GKG) dengan rata-rata hasil 6,7 ton/ha GKG. Padi Inpari 24 ini tahan terhadap penyakit hawar daun bakteri, serta mutu berasnya baik.

Varietas unggul baru inpari 24 yang merupakan beras merah hasil penelitian dari para peneliti Balitbangtan . Inpari 24, mempunyai rasa pulen dibandingkan dengan beras merah local lainnya. Beras merah dikenal karena memiliki pigmen merah yang mengandung senyawa antioksidan yang dipercaya baik bagi kesehatan tubuh. Antioksidan adalah molekul yang menghambat oksidasi molekul lain. Reaksi oksidasi dapat menghasilkan radikal bebas berantai yang dapat menyebabkan kerusakan atau kematian sel. Antioksidan menghentikan reaksi berantai ini dengan menghapus intermediet radikal bebas, dan menghambat reaksi oksidasi lainnya, Olehnya itu, beras merah dipercaya sebagai obat diet bagi penderita kandungan yang demikian itulah, beras merah mendapat tempat yang baik dihati peminatnya, permintaan yang meningkat seiring

Diterbitkan Oleh, 
dengan semakin tingginya kesadaran masyarakat dalam memperhatikan kesehatannya

Penerimaan suatu teknologi oleh petani merupakan proses interpretasi terhadap stimulus yang diterima oleh petani sebelum petani mengambil keputusan untuk menerima atau menolak inovasi tersebut. Persepsi dalam adopsi, merupakan tahap dimana petani sebelumnya memperoleh informasi mengenai varietas unggul baru melalui berbagai media dan metode penyuluhan, kemudian dinilai berdasarkan sifat inovasinya seperti keunggulannya, kemudahannya, kesesuaiannya dapat dicoba dan dapat dilhat (Fachrista dan Sarwendah 2014). Sedangkan teknologi yang diterapkan adalah :Pengolahan tanah , Penggunaan bahan organic, Penggunaan VUB, Penggunaan Benih bersertifikat dan berlabel, Tanam benih 1-3 btg/rumpun. penanaman bibit muda $\leq 21$ hari, Pemupukan spesifik lokasi. Pengendalian OPT, Jarak tanam dengan system Legowo, pengairan berselang, Penyiangan dengan gasrok. panen tepat waktu, dan Pasca panen

Permasalahan yang dihadapi petani saat ini adalah tingkat komsumsi masyaraat akan beras merah masih rendah, selain karna pengetahuan petani tentang manfaat beras merah masih kurang, beras merah harganya mahal dan rasanya pera sehingga kurang diminati. Selain itu di tingkat petani, masih sedikit petani yang mau menanam beras merah. Berdasarkan uraian diatas, maka dilakukan penelitian mengenai respon petani pada penerapan teknologi VUB Padi Inpari 24.

\section{MATERI DAN METODE}

Kegiatan dilaksanakan pada Tahun 2019, di Desa Barabatu, Kecamatan Labbakkang
Kabupaten Pangkep. dengan menggunakan metode survey dengan melibatkan petani pelaksana kegiatan dengan wawancara langsung menggunakan kuesioner terstruktur. Pengambilan sampel dilakukan secara sengaja (purposive), sebanyak 25 orang petani yang telah terlibat dalam demplot penanaman Inpari 24. Data yang diperoleh adalah identitas petani, umur, respon petani terhadap teknologi VUB Inpari 24 Padi.

Analisis menggunakan teknik skor, penentuan skor untuk setiap sifat inovasi teknologi dilakukan terhadap semua komponen teknologi padi. Responden diberi pilihan empat skor (1 sampai 4). Skor 1 ( penilaian sifat inovasi untuk setiap komponen teknologi. Penilaian sifat inovasi berdasarkan kerumitan, keseuaian, mudah diamati, mudah dicoba dan memberikan keuntungan. Sedangkan komponen teknologi padi yaitu: 1 . Pengolahan tanah ; 2. Penggunaan bahan organic; 3. Penggunaan VUB ; 4. Penggunaan Benih bersertifikat dan berlabel ;5. Tanam benih 1-3 btg/rumpun ; 6. penanaman bibit muda $\leq 21$ hari ;7. Pemupukan spesifik lokasi; 8. Pengendalian OPT ;9. Jarak tanam dengan system Legowo : 10. pengairan berselang; 11. Penyiangan dengan gasrok ; 12 panen tepat waktu, dan 13. Pasca panen. Data dianalisis secara deskriptif.

\section{HASIL DAN PEMBAHASAN}

\section{Umur Responden}

Umur seseorang merupakan salah satu hal yang mempengaruhi dalam melakukan usahatani.Di desa Barabatu umumnyara responden berumur antara 20-49 tahun, untuk jelasnya Identitas responden menurut kelompok umur, dapat dilihat pada tabel 1 .

Tabel 1. Identitas responden menurut kelompok umur, Barabatu, Pangkep

\begin{tabular}{lccc}
\hline \multirow{2}{*}{ No } & Kelompok Umur & Frekuensi & Persentase \\
\hline 1 & 50 tahun atau lebih & 5 & 24 \\
2 & $35-49$ Tahun & 8 & 38 \\
3 & $20-34$ Tahun & 12 & 38 \\
& Jumlah & 25 & 100 \\
\hline
\end{tabular}

Diterbitkan Oleh, 
Berdasarkan data pada tabel 1, diketahui bahwa sebagian besar responden yaitu, Sebanyak $8(38 \%)$ responden berusia antara 35-49 tahun dan sebanyak 8 (38\%) responden berusia antara 20-34 tahun. sebanyak 5 (24\%) responden berusia 50 tahun ke atas. Dengan demikian rata-rata responden antara 20-49 tahun yaitu sebanyak 16 (76\%). Hal ini berarti bahwa sebagian besar petani berada pada kelompok umur yang produktif dalam membidangi pekerjaan sebagai petani. Kelompok usia produktif menurut Badan Pusat Statistik Tahun 2010 adalah angkatan kerja yang berada rentang usia antara 22 sampai dengan 50 tahun.

\section{Pendidikan Petani}

Pendidikan merupakan salah satu factor penting dalam penerimaan suatu Teknologi. Untuk mengetahui identitas responden menurut pendidikan dapat dilihat pada tabel 2 .

Tabel 2. Identitas responden menurut pendidikan

\begin{tabular}{clcc}
\hline \multirow{2}{*}{ No } & Tingkat Pendidikan & Frekuensi & Persentase \\
\hline 1 & Lulusan SD & 12 & 48 \\
2 & Lulusan SMP & 5 & 20 \\
3 & Lulusan SMA & 8 & 32 \\
& Jumlah & 25 & 100 \\
\hline
\end{tabular}

Berdasarkan data pada tabel 2 diketahui bahwa sebagian besar responden yaitu, sebanyak 12 (48\%) responden lulus SD, sebanyak 5 (20\%) responden adalah lulusan SMP/Sederajat dan 8(32\%) responden adalah lulusan SMA/Sederajat. Dengan demikian maka sebagian besar responden lulusan SD. Hal ini sesuai dengan ciri masyarakat desa yang pada umumnya memiliki keterbatasan biaya untuk melanjutkan pendidikan, pendidikan bagi mereka bukan prioritas utama, jika responden sudah mampu bekerja dan mendapatkan materi untuk menyambung hidup sehari-harinya maka itu sudah cukup.

\section{Keanggotaan Kelompok Tani}

Kelompok tani merupakan salah satu wadah kelompok tani dalam mengembangkan usaha taninya. Untuk mengetahui identitas responden menurut lama menjadi anggota dalam kelompok tani, dapat dilihat pada tabel 3 .

Tabel 3. Keanggotaan petani dalam kelompok tani

\begin{tabular}{llcc}
\hline No & Lama Menjadi Anggota & Frekuensi & Persentase \\
\hline 1 & $>21 \quad$ tahun & 9 & 43 \\
2 & $16-20$ tahun & 2 & 10 \\
3 & $<10-15$ tahun & 10 & 48 \\
& Jumlah & 21 & 100 \\
\hline
\end{tabular}

Berdasarkan data pada tabel 3 di atas diketahui bahwa sebagian besar responden yaitu sebanyak $10(48 \%)$ responden telah menjadi anggota kelompok tani selama kurang 10 tahun sampai 15 tahun,. Selain itu sebanyak 9 (43\%) responden telah menjadi anggota kelompok tani selama lebih 20 tahun, sedangkan sebanyak 2 responden yang lama pengalamannya 16-20 tahun artinya mereka memperoleh informasi mengenai inovasi teknologi pertanian yang relatif lebih sedikit dibandingkan dengan responden yang sudah lama menjadi anggota kelompok tani. Hal ini bermakna bahwa semakin lama petani menjadi anggota kelompok tani dan semakin sering mengikuti penyuluhan pertanian maka akan memiliki kecenderungan dalam menumbuhkan sikap petani yang positif dalam penerapan teknologi pertanian. 


\section{Kepemilikan Lahan}

Rata-rata kepemilikan lahan sawah yang digarap bervariatif luasannya, ada petani hanya menggarap lahan seluas 0,20 ha sampai ada petani bahkan menggarap 6,00 ha. Adapun status dari lahan garapannya yaitu milik sendiri dan lahan garapan milik orang lain/bagi hasil. Pola tanam di lokasi tersebut rata-rata hanya menanam padi di musim rendengan saja karena jenis lahan yang dikelolah adalah lahan sawah tadah hujan yaitu pertanaman hanya mengandalkan air hujan, selebihnya petani hanya menanam jagung, wijen dan kacang-kacangan tanpa di ikuti oleh teknologi, menanam hanya menghambur kemudian tinggal menunggu hasilnya.

Tabel 4. Penerapan inovasi teknologi VUB inpari 24

\begin{tabular}{|c|c|c|c|}
\hline No & Komponen Teknologi & Penerapan Teknologi & Cara Petani \\
\hline 1 & $\begin{array}{l}\text { Benih } \\
\text { Jumlah (kg/ha) } \\
\text { Varietas } \\
\text { Perlakuan Benih }\end{array}$ & $\begin{array}{l}25 \mathrm{~kg} / \mathrm{ha} \\
\text { Inpari } 24\end{array}$ & $\begin{array}{l}\text { 30-35 kg/ha } \\
\text { Ciherang }\end{array}$ \\
\hline 2 & Pemupukan (dosis kg/ha) & $\begin{array}{c}\text { Urea, NPK,ZA dan } \mathrm{KCl} \\
\text { Sesuai rekomendasi }\end{array}$ & $\begin{array}{c}\text { Urea, NPK } \\
\text { Tidak sesuai rekomendasi }\end{array}$ \\
\hline 3 & Pelakuan pra olah tanah & $\begin{array}{c}\text { Sanitasi lahan dan penyomprotan } \\
\text { herbisida }\end{array}$ & $\begin{array}{c}\text { Sanitasi dan penyemprotan } \\
\text { herbisida }\end{array}$ \\
\hline 4 & Pengolahan tanah & Olah tanah sempurna & Olah tanah sempurna \\
\hline 5 & Cara tanam & $\begin{array}{l}\text { Tapin Jajar Legowo } 2: 1 / 4: 1 \\
\quad(1-3 \text { batang/rumpun })\end{array}$ & $\begin{array}{c}\text { Tegel, } 25 \mathrm{~cm} \times 25 \mathrm{~cm} \\
3-5 \text { batang }\end{array}$ \\
\hline 6 & Jarak tanam (tapin) & $25 \times 12,5 \times 50 \mathrm{Cm}$ & \\
\hline $\begin{array}{l}7 \\
8\end{array}$ & $\begin{array}{l}\text { Umur bibit } \\
\text { Pengairan }\end{array}$ & $\begin{array}{l}15-21 \text { hari } \\
\text { berselang }\end{array}$ & $\begin{array}{l}\geq 21 \text { hari } \\
\text { Tergantung kondisi }\end{array}$ \\
\hline 9 & Penyulaman & 1 minggu setelah tanam & Tergantung kondisi \\
\hline 10 & Waktu Pemupukan & 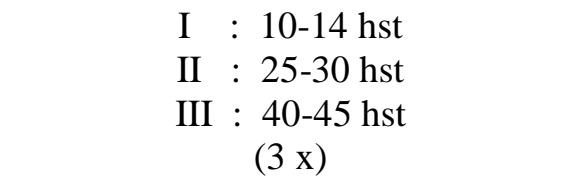 & $1-2$ kali \\
\hline 11 & Penyiangan & Konvensional & \\
\hline 12 & Pengendalian hama penyakit & Preventiff & Bahan kimia \\
\hline 13 & $\begin{array}{l}\text { Panen } \\
\text { - Waktu panen }\end{array}$ & $\begin{array}{l}\text { Masak fisiologis (90\%) menguning, } \\
\text { Kadar air } 25-30\end{array}$ & $\begin{array}{c}\text { Masak fisiologis }(90 \%) \\
\text { menguning, } \\
\text { Kadar air } 25-30\end{array}$ \\
\hline 14 & $\begin{array}{l}\text { Produksi } \\
\text { - Cara panen }\end{array}$ & $\begin{array}{l}\text { 6-7 ton/ha } \\
\text { Mesin Panen }\end{array}$ & $\begin{array}{l}\text { 3- - 4,3 ton/ha } \\
\text { Mesin Panen }\end{array}$ \\
\hline 15 & $\begin{array}{l}\text { Pasca panen } \\
\text { - Pengeringan } \\
\text { - Sortasi } \\
\end{array}$ & $\begin{array}{l}\text { Penjemuran } \\
\text { Blower }\end{array}$ & $\begin{array}{l}\text { Penjemuran } \\
\text { Blower }\end{array}$ \\
\hline
\end{tabular}

Diterbitkan Oleh, 


\section{Penerapan Inovasi Teknologi VUB Padi Inpari 24}

Petani di desa Barabatu umumnya melakukan usaha tani dengan pola tanam padi,padi kacang tanah. Umumnya dalam berusaha tani padi khususnya dalam memproduksi padi menggunaka teknologi sederhana. Adapun Teknologi Produksi Padi Cara petani di Desa Barabatu, Kec. Labbakkang Kab. Pangkep dapat dilihat pada table 4. Produksi varietas unggul baru padi yang ditanam di kelompok tani "Alam Perkasa menghasilkan produksi sebanyak 6,7 ton/ha, dibanding dengan produksi beras biasa yang dilakukan petani sebanyak 3-4 ton/ha. Kelebihan yang dimiliki varietas unggul baru adalah memiliki hasil yang tinggi, pertumbuhan yang seragam sehingga bisa dipanen serempak, mutu hasil lebih baik, tekstur nasi pulen, disukai oleh petani (Mejaya et al. 2014). Selain itu tahan terhadap hama dan penyakit utama, varietas unggul baru mudah diadopsi petani (Endrizal dan Bobihoe 2010; Khadijah et al. 2010). Produksi inpari 24 dapat dilihat pada table 5.

Tabel 5. Hasil penerapan inovasi teknologi VUB padi inpari 24

\begin{tabular}{ccc}
\hline VUB & $\begin{array}{c}\text { Hasil (Penerapan Teknologi) } \\
\text { (ha) }\end{array}$ & $\begin{array}{c}\text { Cara Petani } \\
\text { (ha) }\end{array}$ \\
\hline Inpari 24 & 6,7 ton & $4-4,3$ ton \\
\hline
\end{tabular}

Dari tabel 5. dapat dilihat bahwa produksi hasil Inpari 24 yang diperoleh petani dengan menggunakan komponen teknologi padi adalah sebanyak 6,7 ton/ha, yang lebih tinggi dibandingkan dengan cara petani sebanyak 4,3 ton/ha

\section{Respon Petani Terhadap Teknologi VUB Padi Inpari 24}

Penggunaan Varietas unggul merupakan salah satu komponen teknologi inovatif yang handal untuk meningkatkan produktivitas padi, baik melalui peningkatan potensi atau daya hasil tanaman maupun toleransi dan atau ketahanannya terhadap cekaman biotik dan abiotik (Sembiring 2008). Adopsi penggunaan suatu komponen teknologi, tergantung dari respon petani terhadap suatu teknologi tersebut. Demikian juga pada penggunaan varietas unggul baru oleh petani, petani melihat langsung dari penampilan dari suatu varietas yang dapat diamati secara langsung, mudah diaplikasikan, mudah dilakukan dan menguntungkan hal tersebut sesuai dengan yang disampaikan Mundy, 2000 bahwa suatu inovasi dapat diadopsi oleh petani karena: (1). Memberi keuntungan, perbandingan keuntungan antara peran inovasi teknologi lama dan teknologi baru yang diterapkan oleh petani, (2) kesesuaian (compatibility), yaitu kesesuaian antara inovasi teknologi dan aspekaspek biofisik, keberadaan kelembagaan input produksi, pasar, dan aspek lainnya termasuk sosial budaya di lokasi pengujian, (3) kerumitan (complexity), yaitu tingkat kerumitan dalam tahapan penerapan inovasi teknologi oleh petani, (4) kemudahan untuk diujicoba (trialability), yaitu kemudahan inovasi teknologi untuk di uji coba di lapang oleh petani, baik dari segi biaya maupun resiko kegagalan, dan (5) kemudahan untuk diamati (observability), yaitu kemudahan hasil penerapan inovasi teknologi untuk diamati secara visual oleh petani. Adapun Respon Petani terhadap sifat inovasi VUB inpari 24 dapat dilihat pada tabel 6.

Dari tabel 6 dapat dilihat bahwa penggunaan benih bermutu dan berlabel, , penggunaan bibit muda, Tanam bibit 1-3 batang/rumpun, pengolahan tanah, panen tepat waktu umumnya sudah sesuai/mudah dilakukan oleh petani. Berbeda dengan pemberian bahan organic, system tanam legowo, pemupukan spesifik lokasi, irigasi berselang dan penyiangan dengan gasrok, dan pasca panen masih sulit dilakukan petani. Sedangkan yang sangat mudah dilakukan petani adalah benih bermutu dan berlabel, pengolahan tanah sesuai musim dan pola tanam, dan panen tepat waktu dan gabah segera dirontok. Adapun alasan teknologi masih sulit dilakukan petani adalah : Penggunaan VUB terkendala pada ketersediaan benih unggul Inpari 24 di daerah, dan pemasaran produk hasil, meskipun penerapan

Diterbitkan Oleh, 
teknologi ini memberi keuntungan, tetapi benih beras merah masih sulit diperoleh dan pemasaran hasil masih jadi kendala. Pemberian bahan organik masih belum terbiasa dipraktekkan petani. Sebagian petani yang memelihara ternak sapi /kambing, juga menggunakan pupuk kandang untuk tanaman sayurannya, Kurang diadopsinya penggunaan pupuk organik oleh petani, karena memerlukan tempat dan tenaga kerja yang lebih banyak dan harganya yang semakin meningkat, dianggap kalah efisien dibandingkan pupuk kimia.

Tabel 6. Respon petani pada aplikasi teknologi VUB padi inpari 24

\begin{tabular}{lccccc}
\hline \multicolumn{1}{c}{ Komponen Teknologi Padi } & Kesesuaian & Kerumitan & $\begin{array}{c}\text { Mudah } \\
\text { dicoba }\end{array}$ & $\begin{array}{c}\text { Mudah } \\
\text { diamati }\end{array}$ & keuntungan \\
\hline Penggunaan VUB & 2,14 & 2,20 & 2,13 & 2,82 & 3,11 \\
Benih bermutu dan berlabel & 3,23 & 3,20 & 3,16 & 3,40 & 3,21 \\
Pemberian bahan organik & 2,36 & 2,40 & 2,21 & 3,12 & 2,64 \\
Sistem tanam legowo & 2,12 & 2,31 & 2,13 & 2,7 & 2,95 \\
Pemupukan spesifik lokasi & 2,35 & 1,94 & 2,11 & 2,12 & 2,51 \\
Pengendalian OPT & 2,61 & 2,10 & 2,32 & 2,06 & 2,91 \\
Pengolahan tanah & 3,53 & 3,62 & 3,71 & 3,62 & 3,72 \\
Penggunaan bibit muda & 3,60 & 3,51 & 3,23 & 3,23 & 3,24 \\
Tanam bibit1-3 btg/rumpun & 3,21 & 3,52 & 3,42 & 3,11 & 3,43 \\
Irigasi berselang & 1.92 & 2,4 & 1,81 & 2,21 & 2,41 \\
Penyiangan dengan gasrok & 2,2 & 2,4 & 2,12 & 2,52 & 2,51 \\
Panen tepat waktu & 3,47 & 3,62 & 3,82 & 3,71 & 3,62 \\
Pasca panen & 2,12 & 1,23 & 1,9 & 1,8 & 3,22
\end{tabular}

Keterangan: Skor 1 :sangat tidak sesuai/sangat rumit/sangat sulit/sangat rendah, Skor 2: tidak sesuai/tidak rumit/tidak sulit/rendah, Skor 3: sesuai/mudah/sulit/tinggi, Skor 4: sangat sesuai/sangat mudah/sangat tinggi

Hasil pengkajian menunjukkan rendahnya adopsi teknologi sistem tanam pindah legowo karena penanaman banyak membutuhkan tenaga, upah cara tanam legowo lebih mahal dan memerlukan benih lebih banyak (Erythrina, 2012). Pemupukan spesifik lokasi baik dengan menggunakan alat Bagan Warna Daun (BWD), Perangkat Uji Tanah Sawah (PUTS), Peta Status Hara P dan K, atau Pengelolaan Hara Spesifik Lokasi (PHSL) hanya diimplementasikan oleh sebagian kecil petani dan diberikan secara gratis melalui sistem keproyekan (Nurasa dan Supriadi, 2012), sehingga petani tidak memungkinkan untuk mengadopsi teknologi pemupukan spesifik lokasi. PHSL merupakan pendekatan pemupukan untuk memandu penggunaan pupuk secara rasional dan efisien sesuai dengan kebutuhan tanaman.

Dibandingkan cara manual, penyiangan dengan landak atau gasrok bermanfaat karena ramah lingkungan, hemat tenaga kerja, meningkatkan jumlah udara dalam tanah, dan merangsang pertumbuhan akar lebih baik. Efisiensi dan mahalnya biaya tenaga kerja, menjadi pilihan sebagian petani untuk beralih dari penyiangan dengan landak ke penggunaan herbisida. Strategi program PHT adalah melatih sebagian kecil dari masyarakat petani, bukan untuk melatih semua petani. Dengan demikian, penyebaran pengetahuan PHT mengandalkan difusi dari petani - petani, untuk mengembangkan petani sebagai ahli PHT di lapangan mereka sendiri (Untung, 1996).

Salah satu kendala dalam produksi beras adalah banyaknya beras patah karena proses penggilingan. Hal ini dapat menyebabkan mutu beras menurun (Allidawati dan Kustianto, 1989). Mutu giling merupakan salah satu faktor penting yang menentukan mutu beras. Mutu beras

Diterbitkan Oleh, 
dikatakan baik jika hasil proses penggilingan diperoleh beras kepala yang tinggi dengan beras patah yang rendah. Selain itu pada proses penggilingan, . Penggilingan merupakan proses fisik, yang berpengaruh terhadap kandungan nutrisi beras. Hal ini disebabkan oleh adanya pelepasan dan pengikisan bagian-bagian butiran gabah atau beras selama proses penggilingan yang menyebabkan sebagian nutrisi akan terbuang (Patiwiri, 2006). Beras merah memerlukan penggilingan 2 kali, agar dapat mempertahankan warna merah pada berasnya, pertama yaitu pecah kulit (husking) dan ke dua adalah penyosohan (polishing) untuk mengolah gabah menjadi beras siap komsumsi.

\section{KESIMPULAN}

Ada 2 kategori respon petani pada penerapan teknologi VUB padi Inpari 24 menurut yaitu:

1. Teknologi Sulit dilaksanakan yaitu: Penggunaan VUB, pemberian bahan organik, sistem tanam legowo, pemupukan berdasarkan kebutuhan tanaman dan status hara tanah, pengendalian OPT dengan pendekatan PHT, penyiangan dengan landak/gasrok dan Pasca Panen.

2. Teknologi mudah dilakukan yaitu: penggunaan bibit muda ( $<21$ hari), tanam bibit 1-3 batang per rumpun, penggunaan benih bermutu dan berlabel, pengolahan tanah sesuai musim dan pola tanam, dan panen tepat waktu dan gabah segera dirontok.

\section{DAFTAR PUSTAKA}

Arsyad, D.M. \& E. Jamal. 2011. Kajian Karakter Inovasi Teknologi Padi Sawah Guna Percepatan Adopsinya. Prosiding. Seminar Nasional Pengkajian dan Diseminasi Inovasi Pertanian mendukung Program Strategis Kementerian Pertanian.

Badan Litbang Pertanian. 2007. Pedoman Umum Produksi Benih Sumber Padi. Badan Litbang Pertanian. Departemen Pertanian. $37 \mathrm{hlm}$
Badan Pusat Statistik. 2018. Sulawesi Selatan Dalam Angka

Erythrina, A. Muharam, R. Indrasti, H. Andrianyta, M. Mardiharini, dan U. T. Agustin. 2012. Kajian Sifat Inovasi Teknologi PTT Padi untuk Menentukan Pola Diseminasi Spesifik Lokasi. Laporan Akhir Pengkajian. Balai Besar Pengkajian dan Pengembangan Teknologi Pertanian.

Fachrista, I., A., \& Sarwendah, M. 2014. Persepsi Di Tingkat Adopsi Petani Terhadap Inovasi Pengelolaan Tanaman Terpadu Padi Sawah, Agroekonomika, 3 (1) : 1-10.

Mejaya, M.J., Satoto, P. Sasmita, Y. Baliadi, A. Guswara, dan Suharna. 2014. Deskripsi varietas unggul baru padi. Badan Penelitian dan Pengembangan Pertanian. Jakarta.

Mundy, P., 2000. Adopsi dan adaptasi teknologi baru. Training and Communication Specialist, PAATP3, November 2000. Badan Litbang Pertanian. Jakarta.

Sembiring, H. 2008. Kebijakan penelitian dan rangkuman hasil penelitian BB Padi dalam mendukung peningkatan produksi beras nasional. Prosiding Seminar Apresiasi Hasil Penelitian Padi Menunjang P2BN. Balai Besar Penelitian Tanaman Padi. Sukamandi, Subang.

Sugiono. 2015. Statistik Non Parametris untuk Penelitian.Alfabeta. Bandung

Syam, M. 2006. Kontroversi System of Rice Intensification (SRI) di Indonesia. Iptek Tanaman Pangan, 1(1):30-40.

Purwantiningdyah, D., N., \& Hidayanto, M. 2015. Kajian penerapan pengelolaan tanaman terpadu padi dan keragaan usaha tani padi sawah di Kalimantan Timur. Prosiding Seminar Nasional Masyarakat Biodiversitas Indonesia, 1 (2) : 306-313

Yuliarsih, E. 2019. Potensi Pengembangan Beras Merah di Sulawesi Selatan. Buletin BPTP Sulawesi Selatan.

Untung, K. 1996. Institutional constraints on IPM implementation in Indonesia. Publication of the Pesticide Policy Project 3A: 37-47.

Diterbitkan Oleh, 